\title{
Factors associated with common mental disorders in a hospital cleaning staff
}

\author{
Fatores associados ao transtorno mental comum em trabalhadores de serviço de limpeza \\ hospitalar
}

Márcia Regina Alves Rocha ${ }^{1}$, Maria Jose Sanches Marin², Juana Macias Seda ${ }^{3}$

\begin{abstract}
Objective: to analyze the prevalence and factors associated with common mental disorders in a hospital cleaning staff. Methods: cross-sectional research with 78 cleaners. To identify the common mental disorders, data were collected through a questionnaire with sociodemographic variables and health and work conditions, from the Self Reporting Questionnaire-20. For the analysis, the chi-square test and the Pearson or Spearmann correlation were performed. Results: most participants were female, between 36 and 50 years, brown or black, and lived with a partner. There was a mental disorder prevalence of $25.6 \%$ and an association with hearing problems, dizziness, low back pain, negative health perception, and work satisfaction. The depressive mood stood out among the dimensions of the Self Reporting Questionnaire-20. Conclusion: the factors associated with the common mental disorder were: hearing problems, dizziness, low back pain, negative health perception, and work satisfaction.
\end{abstract}

Descriptors: Mental Disorders; Housekeeping, Hospital; Mental Health; Occupational Health.

Objetivo: analisar prevalência e fatores associados ao transtorno mental comum em trabalhadores de serviço de limpeza hospitalar. Métodos: pesquisa transversal com 78 trabalhadores de serviço de limpeza. Dados coletados por meio de questionário, com variáveis sociodemográficas, condições de saúde e trabalho, do Self Reporting Questionnaire-20 para identificar o transtorno mental comum. Para análise, foi realizado teste de quiquadrado e correlação de Pearson ou Spearmann. Resultados: a maioria era do sexo feminino, idades entre 36 e 50 anos, cor parda ou negra e vivia com companheiro. Prevalência de 25,6\% de transtorno mental e associação deste com problemas auditivos, tontura, lombalgia, percepção negativa da saúde e satisfação com o trabalho. Humor depressivo prevaleceu entre as dimensões do Self Reporting Questionnaire-20. Conclusão: os fatores associados ao transtorno mental comum foram: problemas auditivos, tontura, lombalgia, percepção negativa da saúde e satisfação com o trabalho.

Descritores: Transtornos Mentais; Serviço Hospitalar de Limpeza; Saúde Mental; Saúde do Trabalhador.

\footnotetext{
${ }^{1}$ Universidade Estadual Paulista "Júlio de Mesquita Filho". Botucatu, SP, Brazil.

${ }^{2}$ Faculdade de Medicina de Marília. Marília, SP, Brazil.

${ }^{3}$ Universidade de Sevilha. Sevilha, Espanha. 


\section{Introduction}

The psychosocial factors present in the work environment are considered a complex condition due to multiple influences ${ }^{(1)}$. Therefore, understanding the reasons related to illness at work contribute to direct changes in the aspects that negatively interfere in the conditions of life and health of workers ${ }^{(2)}$.

In the hospital environment, cleaners have an important role in maintaining the environment and in controlling infection. However, they are exposed to biological (human material) and mental risks, due to interactions with patients in the process of death or sickness ${ }^{(3)}$. In addition, the outsourcing that resulted from a greater flexibilization of labor relations has generated a feeling of discrimination between employees with different labor contracts in the same company and with more labor rights ${ }^{(4)}$.

Cleaning service professionals working in hospitals are exposed to increased risks for the appearence of health problems ${ }^{(5)}$. Some of these are mental health problems, which have grown and become a highly significant concern for both public health and the economy ${ }^{(5-8)}$, since they represent more than a third of the total number of disabilities in the Americas, with Brazil at the top of the ranking of disability ${ }^{(8)}$.

Mental disorders can appear through symptoms such as insomnia, fatigue, forgetfulness, irritability, difficulty concentrating, somatic complaints and feelings of worthlessness, in addition to anxiety and depression, and can be generated from high work demands, predominantly among women ${ }^{(5-10)}$.

The cleaning service is a large contingent of workers, who are essential to the hospital environment and perform activities that require routine physical effort, are undervalued, usually under the supervision of nurses and, in society, there has been a trend to develop diseases related to emotional aspects, such as anxiety and depression. In addition, few studies were found that deal with the mental health of these workers, justifying the development of studies that can provide data to contribute to the adoption of policies and actions aimed at the health surveillance of these workers.

Thus, the aim of this study was to analyze the prevalence and factors associated with common mental disorders in a hospital cleaning staff.

\section{Methods}

Quantitative and cross-sectional research carried out with workers from the cleaning staff of a public hospital in the countryside of São Paulo, Brazil. The members of the staff work $12 \times 36$ shifts in compliance with an outsourced service contract, supported by the Consolidation of Labor Laws. They are divided into teams of cleaning auxiliaries, glass cleaners, and cleaning clerks. The work is performed individually, including the terminal cleaning of the rooms, whenever a patient is discharged.

94 workers were invited to participate in the study. To be included they had to be working in the institution for more than six months, considering that for 6 months they have had enough experience to properly evaluate working conditions. Workers who exercised only administrative functions and who were on leave or removed from work for any reason during the collection period were excluded from the study. Four workers had less than six months of work in the function, three had an administrative function, two were on health leave, and seven refused to participate in the study. As a result, 78 workers participated in the study.

A questionnaire containing the following sociodemographic data was applied: gender, age, self-reported skin color, marital status, educational level, presence of underage children at home. For social stratification, the Brazilian Economic Classification Criterion was used, which investigates household consumer goods and the educational level of the head of the family, and then classifies them as follows: Class $\mathrm{A}=45$ to 100 points; Class B1 $=38$ to 44 ; Class B2 = 
29-37; Class C1 = 23 to 28; Class C2 = 17 to 22; Classes D-E $=0$ to $16^{(10)}$.

Other instruments, validated in Brazil, were also included, such as the Self Reporting Questionnaire-20, developed under the coordination of the World Health Organization to identify common mental disorders. This reliable and easy-to-apply instrument contains 20 items, with two possible responses (yes/no) and a high discriminating power for positive cases. The cut off point for this study was defined as eight or more positive responses for women and six or more for men ${ }^{(5,11)}$.

Weight and height were also asked, to calculate the Body Mass Index. In order to evaluate the health conditions, workers were also asked to identify their health problems (muscle pain, bone problems, sleep difficulty, hearing problems, allergies, anxiety, dizziness, heart problems, diabetes, low back pain). For the Self-Perception of Health, researchers asked: In general, compared to people your age, how do you consider your state of health? The answers, in a scale, varied between zero and five, and were distributed as very bad, bad, regular, good, and very good. The higher the score, the better the health perception. These answers were grouped as good and very good, indicating a positive perception; or very bad, bad, and regular, indicating a negative perception.

The data regarding work conditions involved length of service (up to five years, above six years), working hours (day/night), and work satisfaction (satisfied/dissatisfied). As a dependent variable, the common mental disorders variable was used. The other variables mentioned were independent.

The research questionnaire was filled by the researcher through individual interviews in a private place, during working hours, with an approximate duration of one hour. The Free and Informed Consent Term was also signed there. The collection occurred from August 2015 to December 2016.

To analyze the data, descriptive and inferential statistics were used. Absolute (N) and relative (\%) frequencies were calculated for categorical variables. In order to verify the distribution of data normality, the Kolmogorov-Smirnov Test was performed. Pearson's Chi-square test or Fisher's exact test were performed at a significance level of $5 \%$ to verify the level of association between common mental disorders (dependent variable) and other variables. Analyses were carried out with the software Statistical Package for the Social Sciences, version 23.0.

The study complied with the formal requirements in the national and international standards regulating research involving human subjects and was approved by the Ethics Committee, according to protocol number 1.140.406 under Certificate of Presentation for Ethical Appreciation no 45864115.0.0000.5411.

\section{Results}

Among the 78 workers who responded to the data collection instrument, $62(79.5 \%)$ were women $39(50.0 \%)$ were aged between 36 and 50 years old, 43 (55.1\%) were brown or black, and 53 (67.9\%) lived with a partner. From these, 55 (70.5\%) attended more than four years of study and $36(46.2 \%)$ belonged to the $\mathrm{C} 1$ and $\mathrm{C} 2$ economic class, according to Table 1.

The prevalence of common mental disorders among workers in this study was $25.6 \%$. In the statistical analysis, there was no significant association $(p<0.05)$ between having or not common mental disorders and sociodemographic variables.

Table 2 shows the association between the independent variables low back pain $(\mathrm{p}=0.009)$, work satisfaction ( $\mathrm{p}=0.022)$, and positive health perception $(p=0.012)$ with the outcome of mental disorder, with a highest prevalence for those who did not present a common mental disorder. In the association with hearing problems and dizziness, those with common mental disorders were prevalent, $\mathrm{p}=0.014$ and $\mathrm{p}=0.023$, respectively. 
Table 1 - Distribution of hospital cleaners, according to sociodemographic characteristics associated with the presence of common mental disorders $(n=78)$

\begin{tabular}{|c|c|c|c|c|}
\hline Variables & $\begin{array}{c}\text { Without } \\
\text { common } \\
\text { mental } \\
\text { disorders } \\
n=58\end{array}$ & $\begin{array}{c}\text { With } \\
\text { common } \\
\text { mental } \\
\text { disorders } \\
\mathbf{n}=20\end{array}$ & Total & p-value \\
\hline & n(\%) & n(\%) & n(\%) & \\
\hline Gender & & & & $0.749 *$ \\
\hline Female & $45(72.6)$ & $17(27.4)$ & $62(79.5)$ & \\
\hline Male & 13(81.3) & 3 (18.7) & $16(20.5)$ & \\
\hline Age (years) & & & & $0.182^{+}$ \\
\hline $18-35$ & $14(60.2)$ & $9(39.1)$ & $23(29.5)$ & \\
\hline $36-50$ & $31(79.5)$ & $8(20.5)$ & $39(50.0)$ & \\
\hline$>50$ & 13(81.3) & $3(18.7)$ & $16(20.5)$ & \\
\hline Self-reported skin color & & & & $0.121^{\dagger}$ \\
\hline White & $29(82.9)$ & $6(17.1)$ & $35(44.9)$ & \\
\hline Brown/black & $29(67.5)$ & $14(32.5)$ & $43(55.1)$ & \\
\hline Marital status & & & & $0.150^{+}$ \\
\hline With companion & $42(79.3)$ & 11(20.7) & $53(67.9)$ & \\
\hline Without companion & $16(64.0)$ & $9(36.0)$ & $25(32.1)$ & \\
\hline Underage children & & & & $0.300^{+}$ \\
\hline Yes & $27(69.3)$ & $12(30.7)$ & $39(50.0)$ & \\
\hline No & $31(79.5)$ & $8(20.5)$ & $39(50.0)$ & \\
\hline Educational level & & & & $1.000^{*}$ \\
\hline $0-4$ & $17(73.9)$ & $6(26.1)$ & $23(29.5)$ & \\
\hline $5-8$ & $14(77.8)$ & $4(22.2)$ & $18(23.1)$ & \\
\hline $9-11$ & $16(72.7)$ & $6(27.3)$ & $22(28.2)$ & \\
\hline$\geq 12$ & $11(73.3)$ & $4(26.7)$ & $15(19.2)$ & \\
\hline Social class & & & & $0.747^{*}$ \\
\hline $\mathrm{A}+\mathrm{B} 1$ & $9(69.2)$ & $4(30.8)$ & $13(16.7)$ & \\
\hline B2 & $16(76.2)$ & $5(23.8)$ & $21(26.9)$ & \\
\hline $\mathrm{C} 1+\mathrm{C} 2$ & $28(77.8)$ & $8(22.2)$ & $36(46.2)$ & \\
\hline D-E & $5(62.5)$ & $3(37.5)$ & $8(10.3)$ & \\
\hline
\end{tabular}

Table 2 - Distribution of hospital cleaners according to the health and working conditions associated with the presence of common mental disorder $(n=78)$

\begin{tabular}{|c|c|c|c|c|}
\hline \multirow[t]{2}{*}{ Variables } & $\begin{array}{l}\text { Without } \\
\text { common } \\
\text { mental } \\
\text { disorders }\end{array}$ & $\begin{array}{c}\text { With } \\
\text { common } \\
\text { mental } \\
\text { disorders }\end{array}$ & Total & \multirow[t]{2}{*}{ p-value } \\
\hline & $n(\%)$ & $n(\%)$ & $n(\%)$ & \\
\hline \multicolumn{5}{|l|}{ Health conditions } \\
\hline $\begin{array}{l}\text { Common mental dis- } \\
\text { order }\end{array}$ & $58(74.4)$ & $20(25.6)$ & $78(100)$ & 0.000 \\
\hline Body Mass Index> 30 & $12(66.7)$ & $6(33.3)$ & $18(23.1)$ & 0.539 \\
\hline Muscle pain & $28(70.0)$ & $12(30.0)$ & $40(51.3)$ & 0.366 \\
\hline Bone problems & $21(67.7)$ & $10(32.3)$ & $31(39.7)$ & 0.277 \\
\hline Difficulty sleeping & $10(66.7)$ & $5(33.3)$ & $15(19.2)$ & 0.515 \\
\hline Hearing problems & $1(20.0)$ & $4(80.0)$ & $5(6.4)$ & $0.014^{*}$ \\
\hline Allergies & $7(58.3)$ & $5(41.7)$ & $12(15.4)$ & 0.278 \\
\hline Anxiety & $18(72.0)$ & $7(28.0)$ & $25(32.1)$ & 0.785 \\
\hline Dizziness & $3(37.5)$ & $5(62.5)$ & $8(10.3)$ & $0.023^{*}$ \\
\hline Heart problems & $3(60.0)$ & $2(40.0)$ & $5(6.4)$ & 0.598 \\
\hline Diabetes & $3(60.0)$ & $2(40.0)$ & $5(6.4)$ & 0.598 \\
\hline Low back pain & $21(60.0)$ & $14(40.0)$ & $35(44.9)$ & $0.009^{\dagger}$ \\
\hline Health perception & & & & $0.012^{+}$ \\
\hline Positive & $50(80.6)$ & $12(19.4)$ & $62(79.5)$ & \\
\hline Negative & $8(50.0)$ & $8(50.0)$ & $16(20.5)$ & \\
\hline \multicolumn{5}{|l|}{ Work conditions } \\
\hline Satisfaction at work & & & & $0.022^{*}$ \\
\hline Satisfied & $49(80.3)$ & $12(19.7)$ & $61(78.2)$ & \\
\hline Not satisfied & $9(52.9)$ & $8(47.1)$ & $17(21.8)$ & \\
\hline Time working (years) & & & & 0.746 \\
\hline Up to 5 & $48(75.0)$ & $16(25.0)$ & $64(82.1)$ & \\
\hline$\geq 6$ & $10(71.4)$ & $4(28.6)$ & $14(17.9)$ & \\
\hline Working Hours & & & & 1.000 \\
\hline Day & $44(74.6)$ & $15(25.4)$ & $59(75.6)$ & \\
\hline Night & $14(73.7)$ & $5(26.3)$ & $19(24.4)$ & \\
\hline
\end{tabular}


The correlation between those with common mental disorders and those without was significant $\mathrm{p}=0.000$, with a higher prevalence $(74.4 \%)$ of those who did not manifest one.

Regarding the specific dimensions of the common mental disorders, the symptom with the highest percentage was the depressive mood, with 31 positive answers (39.7\%). Among the complaints of this dimension, 43 (55.1\%) reported feeling nervous, tense, worried; and 34 (43.6\%) felt sad lately. The items of the decreased vital energy dimension were manifested by an average of 22.2 participants (28.5\%), and the most common prevalent variables were: Do you find difficult to make decisions (30 - 38.5\%)? Do you get easily tired (25-32.1\%)? (Table 3).

Table 3 - Dimensions of the Self Reporting Questionnaire-20

\begin{tabular}{lc}
\hline Dimensions & $\mathbf{n ( \% )}$ \\
\hline Depressive mood (Mean = 31) & \\
You get scared easily? & $26(33.3)$ \\
Do you feel nervous, tense, worried? & $43(55.1)$ \\
Are you feeling sad lately? & $34(43.6)$ \\
Do you cry more than usual? & $21(26.9)$ \\
Somatic symptoms (Mean = 17.8) & \\
Do you have frequent headaches? & $23(29.5)$ \\
DO you sleep badly? & $26(33.3)$ \\
Do you have stomach discomfort? & $18(23.1)$ \\
Do you have indigestion? & $18(23.1)$ \\
Do you suffer from appetite loss? & $12(15.4)$ \\
Do you have tremors in your hands? & $10(12.8)$ \\
Decrease in vital energy (Mean = 22.2) & \\
Do you get tired easily? & $25(32.1)$ \\
Do you have difficulty making decisions? & $30(38.5)$ \\
Finds it difficult to have satisfaction in your work? & $17(21.8)$ \\
Does your work bring suffering? & $22(28.2)$ \\
Do you have difficulty thinking clearly? & $17(21.8)$ \\
Depressive thoughts (Mean = 9.3) & \\
Do you feel unable to carry on a useful role in your life? & $4(5.1)$ \\
Have you lost interest in things? & $20(25.6)$ \\
\hline Have you thought about ending your life? you feel useless in your life? & $8(10.3)$ \\
\hline
\end{tabular}

\section{Discussion}

The cross-sectional design of this study and the fact that it was performed in a single hospital were limitations to it, making it difficult to verify changes in living, health and work conditions over time. Its findings, however, evidenced the context of a professional category that demands specific care, especially in the promotion of mental health, which should be a priority for the professionals, especially nurses, who are the ones responsible for the health care of the worker.

The results corroborate with other studies carried out among hospital cleaners regarding the predominance of women $^{(3,5)}$, complete high school education, and absence of any association between sociodemographic and labor conditions with common mental disorders ${ }^{(5-6)}$. The predominance of women in this activity is related to the gender inequality that attributes to women activities related to domestic work, a less socially valued activity when compared to those performed by men ${ }^{(3)}$.

The prevalence of the disorder in this study was lower than that of another study that used the same cut-off score with cleaners and within the percentage range, according to studies with the Brazilian female population ${ }^{(5-6)}$.

There was no statistically significant correlation between obesity and common mental disorders, but one third of the obese patients had disorders, as presented by other studies ${ }^{(12-13)}$. Obesity in association with mental disorders is a public health problem that has increased in recent years. Mental disorders favors the development of obesity, just as obesity increases the frequency of mental disorders ${ }^{(13)}$. Depressive states, for example, impair the transmission of hormones involved in regulating mood and metabolism through the hypothalamus, since there is a change in the production of serotonin and leptin. The latter contributes to increased appetite and decreased satiety $^{(14)}$.

Cleaners perform activities that spend energy and increase heart rate, such as lifting chairs, going 
up and down stairs, and terminal cleaning, especially on weekends. But these may not be enough for them to lose weight. It is necessary to consider that foods based on carbohydrates and fats are cheaper and easier to prepare ${ }^{(15)}$.

As for diabetics, the tendency of people with type 2 diabetes to develop depressive disorder is from 15 to $24.0 \%$ higher when compared to non-diabetic patients ${ }^{(16)}$. Therefore, these workers must be identified, and have their health monitored. In this research, people with diabetes who presented common mental disorders were found. There is no consensus on what happens physiologically, but one of the theories is based on the premise that "diabetes has neurochemical effects on the central serotonergic, noradrenergic and dopaminergic systems that diminish the function of these amines" ${ }^{\prime 16: 343)}$.

There was also a significant correlation between hearing impairment and common mental disorders. This prevalence was high compared to another study that associates hearing disorders with the psychic suffering caused by isolation, constraints and frustrations, in addition to the people reporting fatigue due to the mental effort in the communication process ${ }^{(4)}$. Hearing impairment and dizziness, which also had a significant correlation with common mental disorders, may be associated with multiple factors involving the labyrinth and the vestibular apparatus, such as medications, internal conditions, genetic factors and women in the menopause, but there is evidence that anxiety and stress contribute to the appearance of these symptoms that are more common among women and contribute to promote muscle pain due to the contractures to maintain balance ${ }^{(17)}$.

There was an association between the independent variable low back pain and the outcome of mental disorders, according to which those who did not present mental disorders presented a higher prevalence. This finding does not agree with another study ${ }^{(5)}$ that considers the constant repetition of lowering and raising movements as a cause of this symptom. The complaint of muscle pain, even without correlation with the disorder, can not be ignored, since this modality of service is characterized by the concern of the managers in the elimination of idle time, which means: a lot of work in a short time, due to a low number of employees. Workers do not have control over their own work, generating osteoarticular problems, occupational and mental exhaustion, among others ${ }^{(2-3,17)}$.

Pain may also increase the level of anxiety due to difficulties in performing individual activities. Anxiety, in turn, promotes physiological changes, such as increased respiratory rate, tachycardia, and may lead to stress. The response of the organism to the stressors, from the neuroendocrine axes that involve the vestibular system, may be related to the complaint of dizziness $^{(18)}$.

Satisfaction with work had a significant correlation with those who did not present a common mental disorder. The more satisfied, the less likely the person was to present a disorder. Satisfaction is a subjective, intimate emotion, related to a pleasurable feeling, marked by previous experiences, expectations, values that can be linked to both organizational and physical factors as well as interpersonal relationships, going beyond the simple definition of work itself ${ }^{(3-4,7)}$. The dissatisfaction is linked to negative feelings, poor recognition, conflicts between bosses and colleagues and low salaries, which can contribute to mental illness and worsen quality of life $\mathrm{e}^{(1,3-4,7,18)}$. A review of the literature indicates dissatisfaction as a source of damage to physical, mental and social health. It interferes with absenteeism, discharge or permanence at work, as well as on the quality of the service performed, work accidents and user safety ${ }^{(1)}$.

In addition, studies carried out with outsourced workers reveal a feeling of discredit compared to other workers ${ }^{(5,17)}$. Therefore, these situations deserve special attention from the institutions.

Although it is not characterized as pathology, depressive moods reveal mental suffering that generate a decrease in quality of life and can lead to interferences at work ${ }^{(5)}$. Depressive moods, coupled with the decrease in vital energy, may be related to 
the large percentage of women in activity, with smaller children and high loads of domestic tasks after the work shift (12 hours/day), who reported intense physical exhaustion ${ }^{(6)}$. It is estimated, that worldwide, depressive disorders affect more than 300 million people ${ }^{(8)}$. It is estimated to become a major cause of absenteeism $^{(8)}$, and its initial symptoms still go by unnoticed.

In Brazil, in 2015, mental disorders were the third leading cause of years of life lost due to death or disability. Depressive disorders were prevalent among mental illnesses (35.0\%), followed by anxiety (28.0\%) (7). Evidence indicates that work can contribute to the development of depression and suffering, when organizations and work conditions are precarious, including unpleasant work environments ${ }^{(1,19)}$. Depressive moods are more present among women, with ages between 20 and 40 years, with low educational levels, and living with a partner is a protective situation ${ }^{(7,16)}$.

\section{Conclusion}

The independent variables hearing problems, dizziness, low back pain, negative perception of health, and satisfaction with the work were associated with the outcome mental disorder. However, a higher prevalence of hearing problems and dizziness occurred for those who had disorders and the other variables were more prevalent among those who did not manifest common mental disorders. Depressive moods with loss of vital energy were more common among the dimensions of the Self Reporting Questionnaire-20.

\section{Collaborations}

Rocha MRA, Marin MJS and Seda JM contributed in the design, conception, and writing of the article, as well as in a relevant critical review of the intellectual content and in the approval of the final version to be published.

\section{References}

1. Sartoreto IS, Kurgant P. Satisfação e insatisfação no trabalho do enfermeiro. Rev Bras Ciênc Saúde. 2017; 21(2):181-8. doi: http://dx.doi. org/10.4034/RBCS.2017.21.02.12

2. Antunes R, Praun L. A sociedade dos adoecimentos no trabalho. Serv Soc Soc. 2015; 123:407-27. http://dx.doi.org/10.1590/0101-6628.030

3. Berni LB, Beck CLC, Prestes FC, Silva RM, Bublitz $\mathrm{S}$, Lamb F. Indicators of pleasure/pain in hygiene and cleaning outsourced workers of a university hospital. Rev Rene.2016;17(2):155-64. doi: dx.doi. org/10.15253/2175-6783.2016000200002

4. Andrade MO, Cunha VS, Lins WMS, Yung FR, Abdon JAS, Souza EM. Saúde ocupacional e riscos psicossociais em trabalhadores da limpeza de instituição de ensino superior: um estudo qualitativo em Brasília, DF. Tempus Actas Saúde Coletiva. 2016; 10(1):143-56. doi: http://dx.doi. org/10.18569/tempus.v10i1.1859

5. Marconato CS, Magnago ACS, Magnago TSBS, Dalmolin GL, Andolhe R, Tavares JP. Prevalence and factors associated with minor psychiatric disorders in hospital housekeeping workers. Rev Esc Enferm USP. 2017; (51):2-8. doi: http://dx.doi. org/10.1590/S1980-220X2016026303239

6. Senicato C, Azevedo RCS, Barros MBA. Common mental disorders in adult women: identifying the most vulnerable segments. Ciên Saúde Coletiva. 2018; 23(8):2543-54. doi: http://dx.doi. org/10.1590/1413-81232018238.13652016

7. Bonadiman CSC, Passos VMA, Mooney M, Naghavi M, Melo APS. The Burden of disease attributable to mental and substance use disorders in Brazil: Global Burden of Disease Study, 1990 and 2015. Rev Bras Epidemiol. 2017; 20(Suppl 1):191-204. doi: dx.doi.org/10.1590/1980-5497201700050016

8. Pan American Health Organization. The burden of mentaldisordersintheregion of theAmericas, 2018. [Internet]. 2018 [cited Mar 13, 2019]. Available from:http://iris.paho.org/xmlui/bitstream/ handle/123456789/49578/9789275120286_ eng.pdf? sequence $=10$ \&isAllowed $=y$ 
9. Moraes RSM, Silva DAS, Oliveira WF, Peres MA. Social inequalities in the prevalence of common mental disorders in adults: a populationbased study in Southern Brazil. Rev Bras Epidemiol. 2017; 20(1):43-56. doi: http://dx.doi. org/10.1590/1980-5497201700010004

10. Associação Brasileira de Empresas de Pesquisa (ABEP). Critério de Classificação Econômica Brasil [Internet]. 2015 [citado 2019 Mar 11]. Disponível em: http://www.abep.org/criterio-brasil

11. Marcelino Filho A, Araújo TM. Estresse ocupacional e saúde mental dos profissionais do centro de especialidades médicas de Aracaju. Trab Educ Saúde. 2015; 13(Suppl 1):177-99. doi: https:// dx.doi.org/10.1590/1981-7746-sip00016

12. Silva TM, Aguiar OB, Fonseca MJM. Associação entre sobrepeso, obesidade e transtornos mentais comuns em nutricionistas. J Bras Psiquiatr. 2015; 64(1):24-31. doi: http://dx.doi. org/10.1590/0047-2085000000053

13. Santos MM, Nascimento FF, Cabral SMR, Oliveira ES, Santos RM, Carvalho LS. Bilateral relationship between excess weight and mental disorders. Rev Bras Promoç Saúde. 2018; 31(1):1-7. doi: dx.doi. org/10.5020/18061230.2018.6740

14. Associação Brasileira para Estudos da Obesidade e Síndrome Metabólica. Pesquisadores analisam relação entre obesidade e depressão [Internet]. 2017 [citado 2019 mar 12]. Disponível em: http:// www.abeso.org.br/noticia/pesquisadoresanalisam-relacao-entre-obesidade-e-depressao
15. Melca IA, Fortes S. Obesidade e transtornos mentais: construindo um cuidado efetivo. Rev HUPE. 2014; 13(1):18-25. doi: http://dx.doi. org/10.12957/rhupe.2014.9794

16. Linhares BN, Naves, VN, Matias RN, Oliveira JCP, Silva DOF. A correlação entre depressão e diabetes mellitus tipo 2. Rev Med Saúde [Internet]. 2015 [citado 2019 Jan 26];4(3):341-9. Disponível em: https://portalrevistas.ucb.br/index.php/rmsbr/ article/view/6133/4114

17. Bittar RSM, Lins EMDS. Clinical characteristics of patients with persistent postural-perceptual dizziness. Braz J Otorhinolaryngol. 2015; 81(3):276-82. doi: https://doi.org/10.1016/j. bjorl.2014.08.012

18. Moraes CF, Silva NP. Saúde mental e as relações de trabalho: como a ansiedade influencia o comportamento humano no ambiente de trabalho. Rev Interface Saberes [Internet]. 2015 [citado 2019 Abr 11];14(1):1-16. Disponível em: https:// interfacesdesaberes.fafica-pe.edu.br/index.php/ import1/article/view/533/274

19. Batista JBV, Carlotto MS, Oliveira MN, Zaccara AAL, Barros EO, Duarte MCS. Mental disorders in university teachers: study in a service of medical investigation. J Res Fundam Care Online 2016; 8(2):4538-48. doi: http://dx.doi. org/10.9789/2175-5361.2016.v8i2.4538-4548 